Proc. Estonian Acad. Sci. Geol., 2002, 51, 3, 180-192

\title{
Stable isotope and pollen stratigraphy in marl sediments from Lake Ilmjärv (central Estonia)
}

\author{
Jaan-Mati Punning ${ }^{\mathrm{a}}$, Tiiu Koff ${ }^{\mathrm{a}}$, Tõnu Martma ${ }^{\mathrm{b}}$, and Göran Possnert ${ }^{\mathrm{c}}$ \\ a Institute of Ecology, Tallinn Pedagogical University, Kevade 2, 10137 Tallinn, Estonia; \\ mati@eco.edu.ee \\ ${ }^{\mathrm{b}}$ Institute of Geology, Tallinn Technical University, Estonia 7, 10143 Tallinn, Estonia; \\ martma@gi.ee \\ c Ångström Laboratory, Uppsala University, Box 534, S-751 21 Uppsala, Sweden; \\ Goran.Possnert@Angström.uu.se
}

Received 3 September 2001, in revised form 23 January 2002

\begin{abstract}
The aim of the present research was to reconstruct trends in the environmental changes and estimate the importance of the rapid change of $\delta^{13} \mathrm{C}$ in the Boreal as a stratigraphic marker by comprehensive study of stable carbon and oxygen isotopes and pollen from the lake marl section of Lake Ilmjärv (c. 2.5 ha closed lake situated in the Vooremaa drumlin area). The $\delta^{13} \mathrm{C}$ and the $\delta^{18} \mathrm{O}$ values reached their maxima near the end of the Boreal, then dropped and were practically constant up to the top of the marl sequence c. 3000 BP. These changes were accompanied by a remarkable improvement of climatic conditions and shifts in the vegetation.
\end{abstract}

Key words: lake marl, carbon and oxygen isotopes, pollen analysis, isotope stratigraphy, Estonia.

\section{INTRODUCTION}

Sediments deposited in carbonate-precipitating lakes may contain carbon- and oxygen-isotope records of a climatic change (Whittington et al. 1996). As the authigenic calcite precipitates during the spring/summer photosynthetic bloom, the isotopic records reflect the equilibrium conditions (temperature and isotopic ratio in lake water, when local evaporation and direct precipitation have their strongest isotopic effects; e.g. Punning et al. 1984; Kelts \& Talbot 1990; Eicher 1995). The direct relationship between temperature in the water and oxygen isotopic composition of precipitated carbonates is still unclear. Among the factors that determine the carbon isotope content in the precipitated carbonates are the origin and composition of the carbon carried from the catchment by runoff and by groundwater, the biological production within the basin and the isotopic 
equilibrium between atmospheric carbon dioxide and bicarbonate in the lake (McKenzie 1985; Talbot 1990; Wachniew \& Rozanski 1997; Hu et al. 2000). Nevertheless, the isotopic curves of authigenic and biogenic carbonates have found wide use in palaeoenvironmental research, principally for the reconstruction of general trends but also for the study of the dynamics of climatic conditions (Lotter et al. 1992; Gat \& Lister 1995).

The pollen spectra reflect mainly integrated long-term changes in the forest composition and thus the trends of mean climatic variables in a certain area. So, by combining both approaches it is possible to study the dynamics of different environmental processes in the area surrounding a lake. In our earlier studies, we pointed out that the state and the dynamics of the ecosystems in a mosaic of glacial landscapes may differ considerably because of the variety of the physical environment at different scales (Punning \& Koff 1997).

The aim of the present research was to study isotopes and pollen from lake marl to reconstruct the trends in the environmental changes and the rapid change of $\delta^{13} \mathrm{C}$ during the Boreal as a stratigraphical marker. Our earlier investigations (Punning et al. 2000) demonstrated that differences in $\delta^{18} \mathrm{O}$ and $\delta^{13} \mathrm{C}$ values for layers accumulated during the Pre-Boreal (10 000-9000 BP) and Boreal (9000-8000 BP) chronozones (Raukas et al. 1995) are significant and caused partly by the changing climatic conditions around the Ancylus Lake stage in the development of the Baltic.

\section{STUDY SITE}

Palynological and isotopic investigations were conducted on a sediment core with Holocene sediments from the littoral part of Lake Ilmjärv. Ilmjärv $\left(26^{\circ} 30^{\prime} \mathrm{N}\right.$ and $58^{\circ} 35^{\prime} \mathrm{E}$ ) is situated in the Vooremaa drumlin field in Estonia (Fig. 1). At the beginning of the Older Dryas varved clays accumulated in the deep-water interstitial troughs (Pirrus et al. 1987b). The water level dropped abruptly in the first half of the Older Dryas and independent lakes formed in the deepest parts of the inter-drumlin hollows. At that time also terrigenous lacustrine sediments started to accumulate.

The Vooremaa drumlin field lies in the East and Central Estonian spruce and mixed spruce forests region (Laasimer 1965). An extensive mixed woodland area with abundant broad-leaved tree species, e.g. Fraxinus excelsior, Acer platanoides, Quercus robur, Tilia cordata, and Ulmus laevis, occurs in the northern part of the drumlin field.

Ilmjärv is a small (2.5 ha) closed lake with a maximum water depth of $6.2 \mathrm{~m}$ and mean depth of $4.2 \mathrm{~m}$. Its shores are mainly swampy, only in the southeastern part they are more hilly. The water in the lake is yellowish-green and mineralrich. At present the lake is eutrophic.

The lithological composition of sediments in and around Ilmjärv has been studied in detail earlier (Pirrus 1983). According to that lake marl is homogeneous 


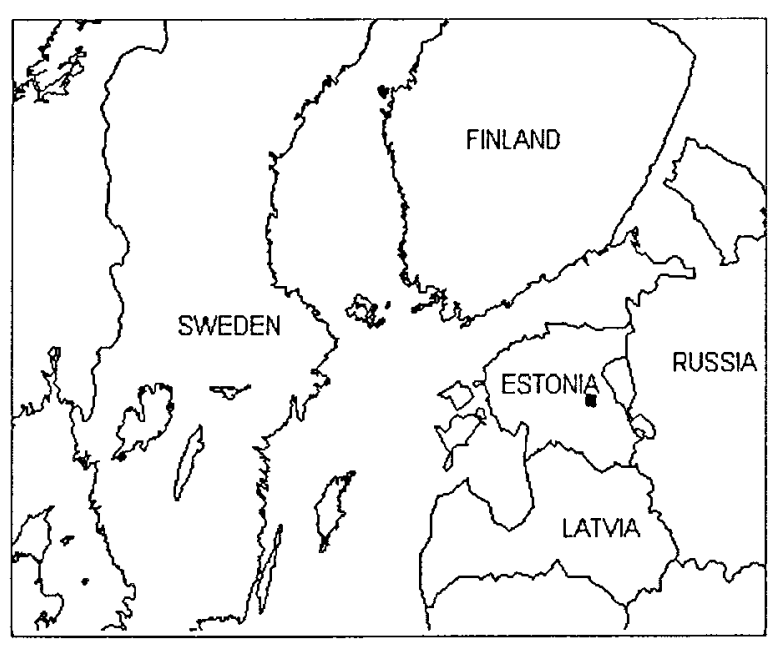

Fig. 1. Location of the study site.

and the content of carbonates in cores varies from 80 to $92 \%$ (mainly calcite, content of dolomite $2-6 \%$ ). In the core studied by us lake marl lies on silt at a depth of $872 \mathrm{~cm}$ from the sediment surface. The contact with the above-lying Phragmites peat is sharp at a depth of $289 \mathrm{~cm}$.

\section{MATERIALS AND METHODS}

The cores were taken with a Russian-type sampler from the paludified northeastern shore of Ilmjärv, wrapped in plastic, and stored in a deep freezer. One-centimetre block samples were taken at $25 \mathrm{~cm}$ intervals for initial pollen and stable isotopic analyses, and contiguous samples at $0.5 \mathrm{~cm}$ were taken at a depth of $835-840 \mathrm{~cm}$. The samples were dried at $105^{\circ} \mathrm{C}$. The percentages of total organic matter and of $\mathrm{CaCO}_{3}$ were estimated by loss on ignition at 550 and $950^{\circ} \mathrm{C}$, respectively (Fig. 2). Samples for radiocarbon dating were sieved on a $250 \mu \mathrm{m}$ sieve, and terrestrial plant remains, such as needles, fruits, and catkin scales, were dated at the Ångström Laboratory, Uppsala University.

The stable-isotope analyses were carried out in the Institute of Geology at Tallinn Technical University on a Delta E (Finnigan MAT) mass spectrometer. Marl was decomposed in $100 \%$ phosphoric acid at $50{ }^{\circ} \mathrm{C}$. The results are presented in the usual $\delta$ notation, as per mil deviation from the VPDB standard. Reproducibility of replicate analyses was generally better than $0.1 \%$.

For pollen analysis a dried sample of $50 \mathrm{mg}$ was treated with $10 \% \mathrm{HCl}$, followed by the standard acetolysis of Moore \& Webb (1978). The basis for percentage calculations of the data was the sum of arboreal (AP) and nonarboreal 


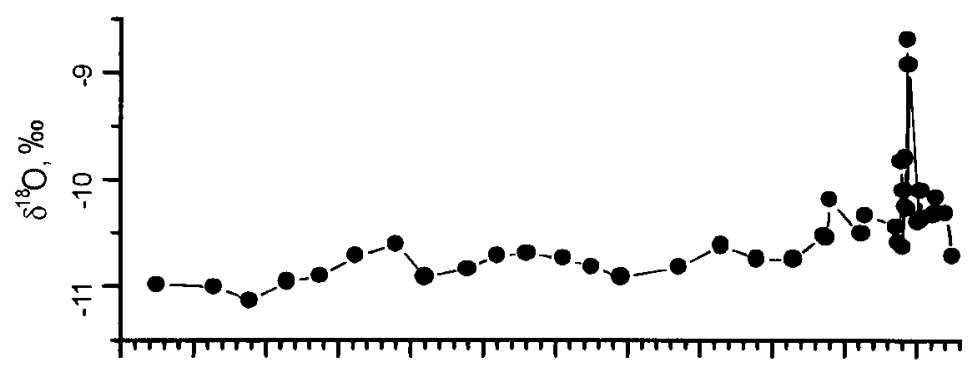

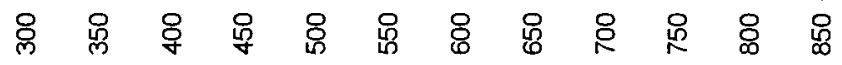
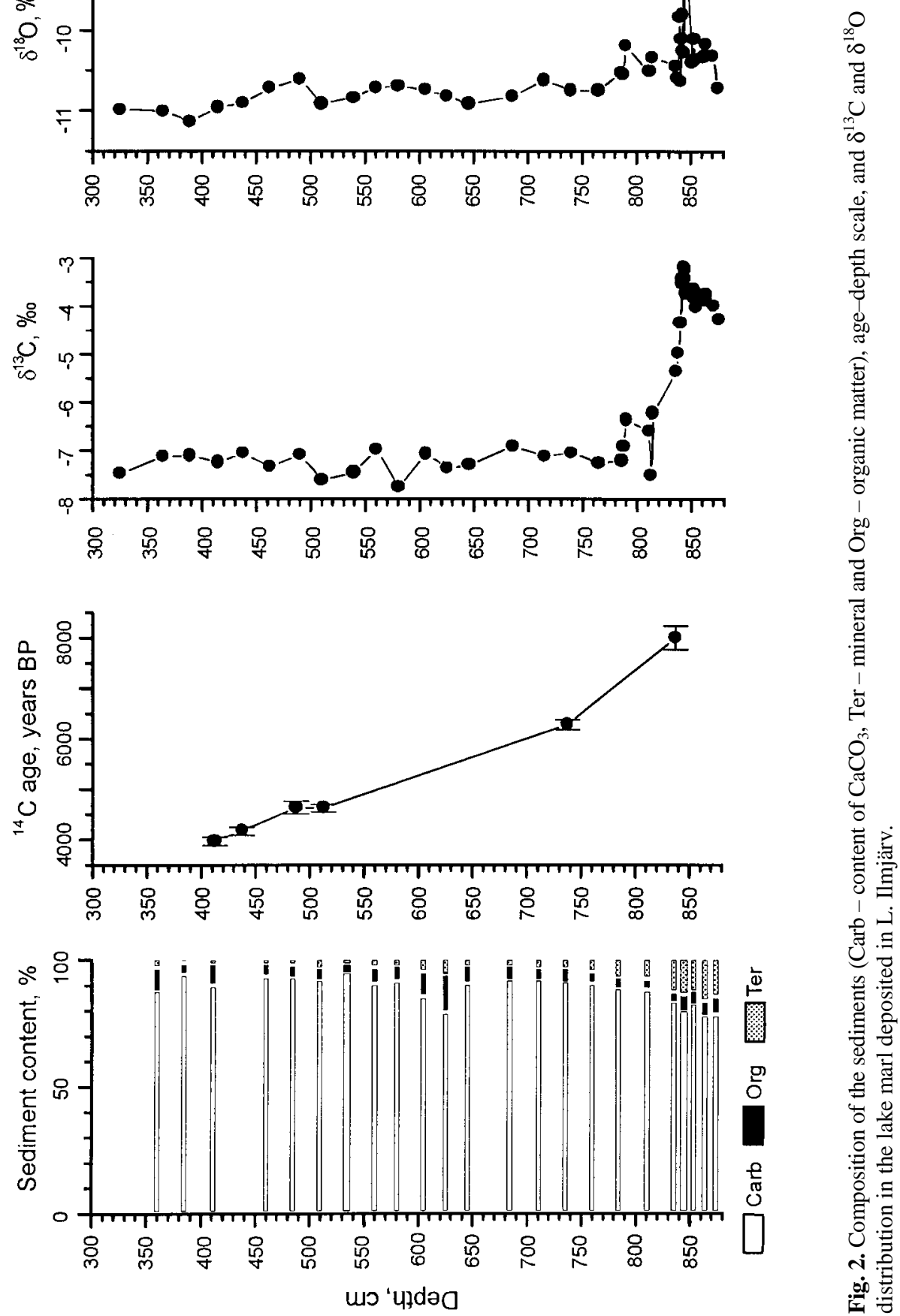
pollen (NAP). The minimum count for AP was 500 grains. Lycopodium tablets were added to estimate the pollen concentration. The pollen diagram was drawn by the TILIA-GRAPH program (Grimm 1990).

\section{RESULTS AND INTERPRETATION}

Six macrofossil samples from lake marl from the Ilmjärv section were dated by the AMS radiocarbon method (Table 1). Based on the obtained data, the mean sedimentation rate at the beginning of the Atlantic (8000-6300 BP) was c. $0.06 \mathrm{~cm} \mathrm{yr}^{-1}$, and thereafter had a rather constant value of approximately $0.14 \mathrm{~cm} \mathrm{yr}^{-1}$ up to c. $4000 \mathrm{BP}$ (Fig. 2). The lake marl is homogeneous and the content of carbonates in the samples ranges from 78 to $94 \%$ (Fig. 2). The carbonates are composed mainly of calcite. The content of terrigenous material in the basal layers of the marl is about $15 \%$, decreasing to 5-8\% upwards. The content of the organic matter is rather even (5-10\%) throughout the marl (Fig. 2).

Table 1. AMS radiocarbon dates from Lake Ilmjärv

\begin{tabular}{|c|c|c|c|c|}
\hline $\begin{array}{l}\text { Sample } \\
\text { depth, } \\
\text { cm }\end{array}$ & $\begin{array}{l}\text { Laboratory } \\
\text { number }\end{array}$ & Macrofossils submitted & $\begin{array}{l}{ }^{14} \mathrm{C} \text { age, } \\
\text { yr BP }\end{array}$ & $\begin{array}{c}\delta^{13} \mathrm{C} \\
\% \circ \mathrm{PDB}\end{array}$ \\
\hline $410-415$ & Ua-16570 & Pinus sylvestris $(\mathrm{TR})$ & $3975 \pm 85$ & -29.5 \\
\hline $435-440$ & Ua-16571 & Betula pubescens $(\mathrm{F} \& \mathrm{CS})$ & $4170 \pm 75$ & -27.4 \\
\hline $485-490$ & Ua-16572 & Betula pubescens $(\mathrm{F} \& \mathrm{CS})$; Picea abies $(\mathrm{N})$ & $4635 \pm 125$ & -28.0 \\
\hline $510-515$ & Ua-16573 & Betula pubescens (F\&CS); Pinus sylvestris (TR) & $4620 \pm 75$ & -28.7 \\
\hline $735-740$ & Ua-16574 & Betula pubescens $(\mathrm{TR})$ & $6280 \pm 100$ & -28.1 \\
\hline $835-840$ & Ua-16575 & Betula pubescens $(\mathrm{F})$ & $8005 \pm 235$ & -27.8 \\
\hline
\end{tabular}

$\mathrm{N}$, needles; F\&CS, fruits and catkin scales; TR, tissue remains.

The curves of $\delta^{18} \mathrm{O}$ and $\delta^{13} \mathrm{C}$ have similar morphology, with peaks at a depth of about $845 \mathrm{~cm}$, followed by small variations (Fig. 2). The maximum of $\delta^{13} \mathrm{C}$ values at $843-845 \mathrm{~cm}$ is especially noteworthy (Fig. 3). After a short period the isotope values drop sharply and remain practically constant up to the top of the marl sequence (c. $3000 \mathrm{BP})$. The $\delta^{13} \mathrm{C}$ maximum $(-3 \%$ ) is comparable to values for other Estonian sites (Punning et al. 2000).

The maximum $\delta^{18} \mathrm{O}$ values $(-8.7 \%$ ) occurred at a depth of $843-845 \mathrm{~cm}$, followed by a decreasing trend (Figs. 2 and 3). Similar to other Estonian lake marls, the $\delta^{18} \mathrm{O}$ values between -10.5 and $-11 \%$ o were recorded in the sediments formed c. 8000-4000 BP in the Atlantic and Sub-Boreal. Data for the years 1982-85 from the Tiirikoja Meteorological Station (in northeastern Estonia) on the isotopic composition of precipitation provided a monthly $\delta^{18} \mathrm{O}$ weighted mean value of $-10.4 \%$. The corresponding values for groundwater in northern Estonia are from -10.8 to $-12.8 \%$ (Punning et al. 1987). This suggests that correlation 

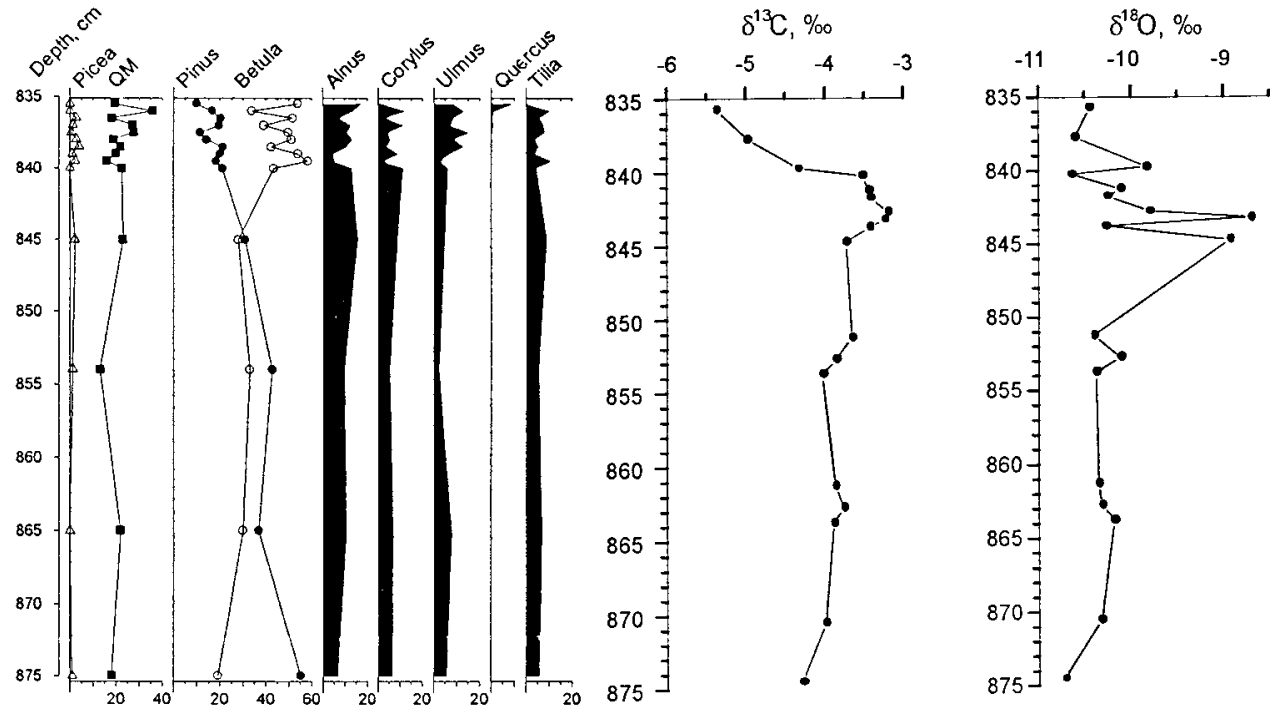

Fig. 3. Fine-scale pollen percentage diagram and $\delta^{13} \mathrm{C}$ and $\delta^{18} \mathrm{O}$ distribution in the lake marl layers from depths of $835-875 \mathrm{~cm}$.

exists between the isotopic composition of precipitation and groundwater, related to their mainly atmospheric origin (Punning et al. 2000). According to the isotopic data it seems that there were no essential differences during the Holocene in the atmospheric circulation regime compared to the present and that $\delta^{18} \mathrm{O}$ variations have been caused by regional trends in the environmental conditions.

The pollen diagram (Fig. 4) is similar to other diagrams for the Vooremaa drumlin field (Pirrus et al. 1987a, 1987b). The content of broad-leaved pollen types, Quercetum mixtum (QM) up to $40 \%$ is higher than typical of Estonia (Laasimer 1965) even during their maximum in the Atlantic. The values of Pinus pollen (20-30\%) are low throughout the Holocene, including the Boreal. That period in Estonia is characterized as the Pinus maximum (Raukas et al. 1995). In Ilmjärv sediments the values of Pinus pollen are higher (60\%) only at the very beginning of the marl sedimentation and decrease rapidly to $20 \%$ by the end of the Boreal (8000 BP). Picea pollen is continuously present from the beginning of the Atlantic but reaches its maximum during the Sub-Boreal around $3500 \mathrm{BP}$, when the content of pollen of broad-leaved trees and alder starts to decrease rapidly.

As this research focused on the time span around $\delta^{13} \mathrm{C}$ and $\delta^{18} \mathrm{O}$ maxima, the samples from a depth of $835-840 \mathrm{~cm}$ were selected for detailed studies, and pollen samples at $5 \mathrm{~mm}$ intervals, comprising approximately 5-7 years, were analysed. The fine-scale pollen percentage diagram from this interval shows a slight increase in the content of QM, increase in the Betula pollen content, and a decrease in Pinus (Fig. 3). Among QM the dominating pollen type is Ulmus, followed by Corylus and Tilia. The pollen influx diagram from the same section (Fig. 5) demonstrates these changes in more detail. 


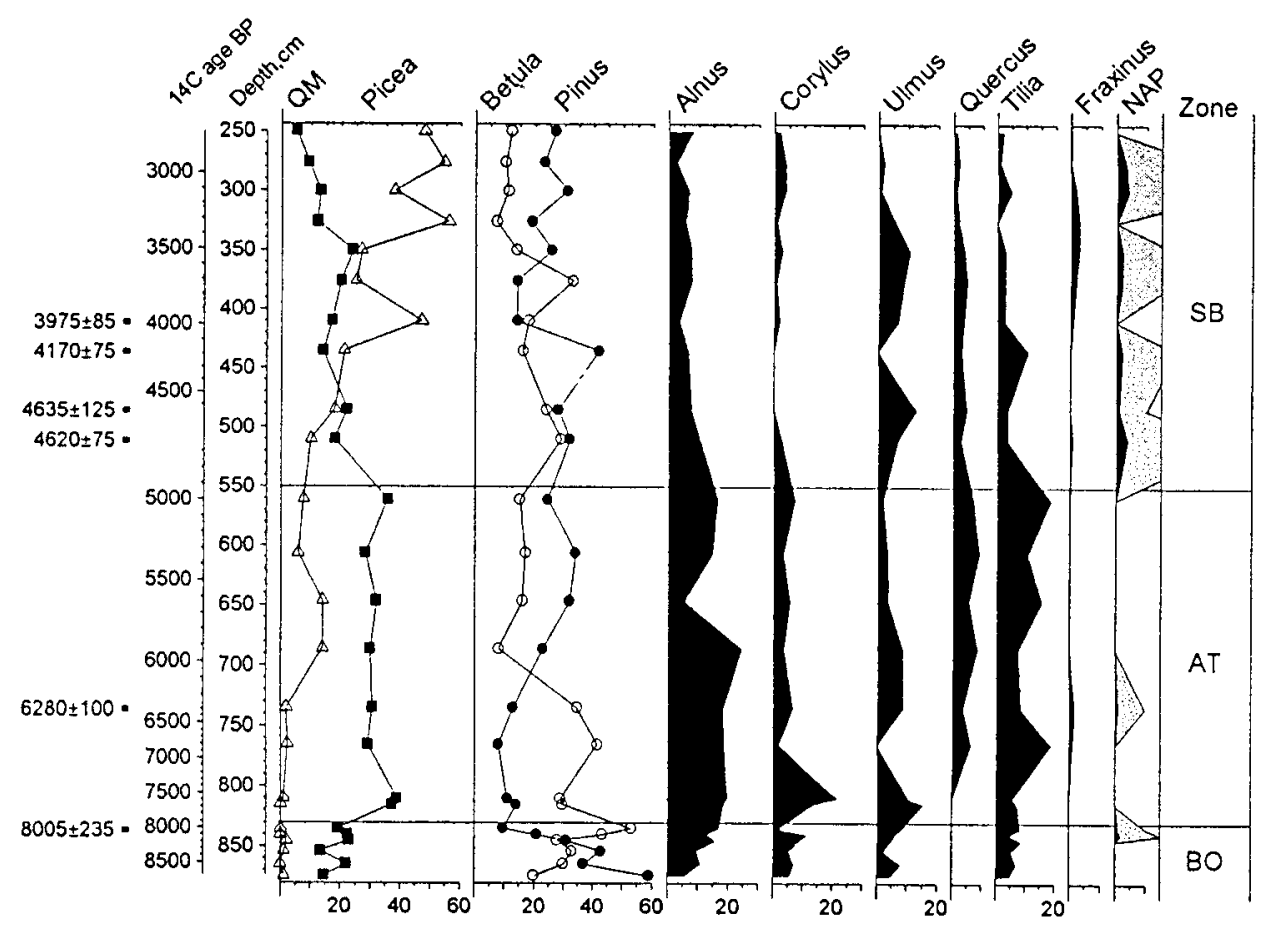

Fig. 4. Basic pollen percentage diagram.
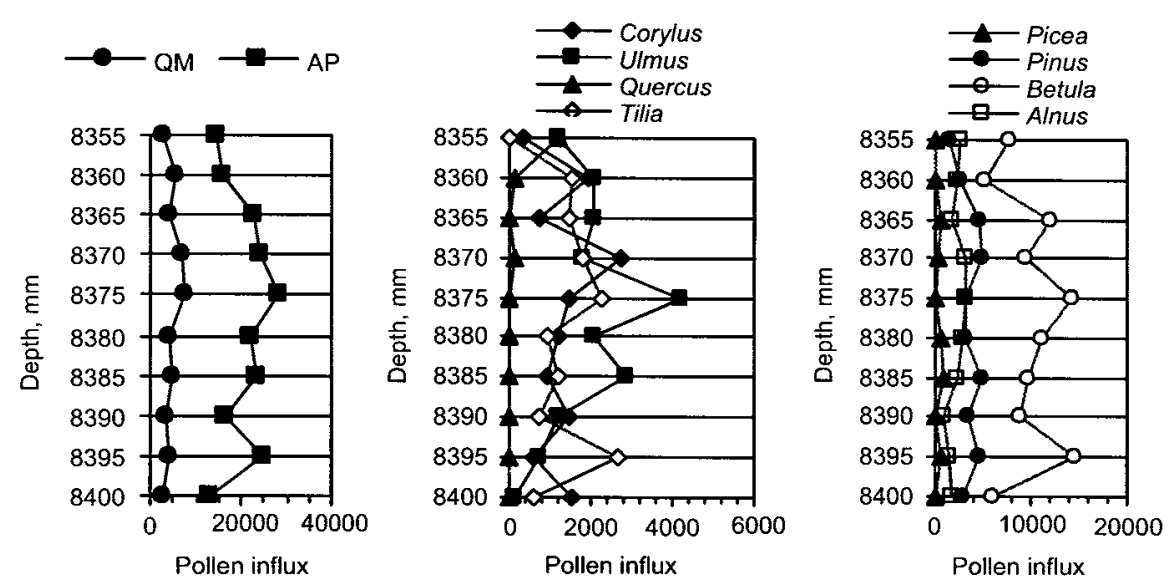

Fig. 5. Fine-scale pollen influx (number of pollen grains $\mathrm{cm}^{2} \mathrm{yr}^{-1}$ ) diagram for total tree (AP) and sum of broad-leaved trees $(\mathrm{QM})$ and various tree pollen types. 


\section{DISCUSSION}

Establishing the changes in the environmental conditions on the basis of comprehensive analysis of isotope and pollen data is complicated due to great differences in the response of isotopes and vegetation to the changing climatic conditions. The changes in the pollen content are as a rule slower, and the timelag after changes in hydrometeorological conditions are always longer than twice the mean age of a forest stand (Punning et al. 1997). The changes in the isotope composition are much faster because of high kinetics of isotope fractionation (Punning et al. 2000). Smoothed one-way trends may result from the stable period in carbonate sedimentation (Hu et al. 2000). On the Ilmjärv isotope records both types are represented. Of special interest are the rapid changes in the light isotope content, especially in $\delta^{13} \mathrm{C}$ in the sediments formed around $8000 \mathrm{BP}$ at a depth of $835-840 \mathrm{~cm}$ (Fig. 2).

The sharp decrease in the $\delta^{13} \mathrm{C}$ values of precipitated marl at a depth of 840 $\mathrm{cm}$ about $8000 \mathrm{BP}$ in the L. Ilmjärv section as well as in the sections studied by us earlier (Punning et al. 2000) most probably results from the impact of biogenic (and hence isotopically light) $\mathrm{CO}_{2}$ transported from the catchment. Higher organic-matter productivity within the lake was not the cause, because decomposition of organic matter in the hypolimnion will decrease the $\mathrm{pH}$ and hinder the formation of $\mathrm{CaCO}_{3}$ (Dean 1999). Thus, the background factors determining the decrease in the $\delta^{13} \mathrm{C}$ values of lake marl in the Ilmjärv section are the soil processes and formation of organic matter in the lake catchment. The $\delta^{13} \mathrm{C}$ values can thus be expected to vary in response to palaeoenvironmental, particularly biological changes, both in the catchment and in the lake itself.

The oxygen isotope content of the marl supports our assumption about the abrupt deterioration of climatic conditions during the Boreal (Punning et al. $2000)$. The $\delta^{18} \mathrm{O}$ values have their maximum $(-8.7 \%$ ) in the marl accumulated in Ilmjärv at a depth of $843-845 \mathrm{~cm}$ (Fig. 3). The $\delta^{18} \mathrm{O}$ values may have peaks also in layers formed during the late Boreal and at the beginning of the Atlantic. This is in good agreement with the oxygen isotope ratio for the Early Holocene marl in lakes Võrtsjärv, Tamula, Sinijärv (Punning et al. 2000), and Saarijärvi (southern Finland) (Brauer 1990). After a short maximum $\delta^{18} \mathrm{O}$ values fell to approximately the same level as today (about $-11 \%$ in the surface marl in Sinijärv) and carbonate sedimentation took place under nearly equilibrium conditions.

This supports our previous conclusion that by isotope data the warmest conditions existed in the early Holocene, earlier than estimated by pollen data (Punning et al. 1984). This maximum is most vividly reflected in the Vaharu section near the ancient Ancylus Lake shoreline as a $3 \%$ increase in the $\delta^{18} \mathrm{O}$ values 9000-8000 BP. We explained the increase in the Lake Vaharu section by the sharp continentalization during the isolation of the Baltic Sea from the Atlantic Ocean. The slight decrease in the $\delta^{18} \mathrm{O}$ values in the Ilmjärv sediments (Fig. 2) from a depth of $790 \mathrm{~cm}$ upwards (during the Atlantic) speaks about a permanent fall of late-summer to autumn temperatures and/or a decrease in evaporation due to an increase in humidity. 
Pedogenesis, responsible for the shift in the carbon isotope content in the deposited marl, was at that time determined by hydrological conditions and the development of vegetation. In most pollen diagrams from Estonia the Boreal was most crucial. In addition to Pinus and Betula present already in the Pre-Boreal, the climatic conditions improved during this 1000-radiocarbon year period and the vegetation became denser and mosaic. Pollen diagrams from the Vooremaa area (Pirrus et al. 1987a, 1987b) show a strong order in the emergence of different taxa. Alnus and Ulmus appear almost together in the pollen diagram, followed by Corylus and later by Tilia.

How can we describe the vegetation of this period? The ecological demands of these taxa are rather variable. Corylus is nowadays growing on calcareous soils and demands very much light. Ulmus can grow also under the shadow and on moist soils around lakes or rivers. The same conditions are favourable for Alnus. Tilia cannot grow in the conditions of overmoisture. A common feature for all these taxa is that they have high demands on soil fertility. The previous studies explaining the forest history during the Boreal in Estonia (Laasimer 1965) describe the forest of that period mainly as pine dominated forest with single Ulmus and Corylus. However, our pollen influx data from Ilmjärv disagree with this conclusion. The influx of broad-leaved trees in the range 1500-4500 pollen grains $\mathrm{cm}^{2} \mathrm{yr}^{-1}$ (Fig. 5) is more than 10 times higher than contemporary data obtained by us using Tauber traps exposed in the nearest vicinity of single broadleaved trees (Koff 2001). According to the pollen influx data, the vegetation in the Boreal around Ilmjärv was dominated by birch that was growing on the lakeshore and therefore gave a high pollen influx. The influx values for Alnus are comparable to the present situation. Pinus influx has rather low but stable values, which means that it has a permanent share in the forest composition. Competitive taxa were most probably Ulmus and Corylus: their influx values are reverse (Fig. 5). Their high influx values confirm that they were also constantly present in the forest composition. The NAP values are extremely low and represented only by a few Cyperaceae grains. This means that there was a rather dense forest without any large openings in the nearest vicinity of the lake. The AP values are between 10000 and 28000 pollen grains $\mathrm{cm}^{2} \mathrm{yr}^{-1}$. That is comparable to the influx values from the surface samples of different Estonian lake sediments (Koff et al. 2000), sediment traps in lakes (Koff 1998), and modern pollen traps (Koff 2001) in densely forested areas. Pollen influx values from the Ilmjärv sediments confirm that the surroundings of this lake were covered by dense, mixed deciduous forest. The changes in the vegetation from coniferous forest to the deciduous one caused also differentiation of soils and an intensification of physical and chemical weathering. The fine-scale pollen diagram (Fig. 4) shows that the decline in the $\delta^{13} \mathrm{C}$ value is associated with the changes in the content of Betula and Pinus pollen at a depth of $845 \mathrm{~cm}$ and the slight increase in the pollen of broad-leaved trees.

The similar trends in the isotopic content of lake marl at the sites studied earlier clearly indicate that environmental conditions changed in Upper Estonia 
and South Finland during the Boreal. This sharp decline in $\delta^{13} \mathrm{C}$ to negative values is represented in many studied cores in Estonia (Punning et al. 2000) and Lake Saarijärvi from southern Finland (Brauer 1990). The similar morphology of $\delta^{13} \mathrm{C}$ profiles from the sites of Tamula, Sinijärv, Vaharu, and Võrtsjärv (Punning et al. 2000), lakes with very different size and hydrological regime, shows that some general factors determined the formation of the carbon isotope composition in the lake marls. A similar event was described by Hammarlund et al. (1997), who showed that a significant decrease in $\delta^{13} \mathrm{C}$ values, up to 5\%, was initiated shortly before $10000 \mathrm{BP}$. This decrease is represented in the organic component of the sediments as well in lake marl. The data by Hammarlund et al. (1997) support the idea that mainly processes of local and regional importance, first of all pedogenesis (Reintam 1996), related to the development of the vegetation (climate) are responsible for the observed $\delta^{13} \mathrm{C}$ decrease in the lake sediments studied by us. The $\delta^{13} \mathrm{C}$ variations upwards in the lake marl core from Ilmjärv are relatively small, around $-7.5 \%$. The similarity of all isotope records is expressed by the comparable, high values of $\delta^{13} \mathrm{C}$ in the marl accumulated during the Boreal (from -3.5 to $-4.0 \%$ ) and in the sharp depletion of heavy isotopes in the marl about $8000 \mathrm{BP}$. Therefore it seems that this decline in $\delta^{13} \mathrm{C}$ values might be used as a stratigraphical stratum for this region. While in a previous work (Punning et al. 2000) we dated this event indirectly using pollen diagrams, then now it was possible to date the event by ${ }^{14} \mathrm{C}$ as $8000 \mathrm{BP}$.

\section{CONCLUSIONS}

The isotope and pollen study of lake marl deposited in L. Ilmjärv shows that there was intensive authigenic carbonate deposition since the Boreal up to the Sub-Atlantic. The isotope content and pollen spectra in the Ilmjärv core reflect an integrated impact of a whole complex of environmental conditions. As the isotopic events are temporally synchronous in lakes with different size and hydrology, we assume that pedogenesis was the final, common factor of principal importance in the formation of the carbon and oxygen isotope content of authigenic carbonates in the lake as well in shaping the main features of the vegetation. Namely, this process is determined by the complex of hydrometeorological changes and, in turn, is essential in the leaching of minerals from the catchment and the formation of habitats for vegetation.

The covariance between $\delta^{13} \mathrm{C}$ and $\delta^{18} \mathrm{O}$ values as well as changes in the pollen spectra are a reflection of climatically controlled dynamics where the residence time evolution plays a significant role. The sharp shift in $\delta^{13} \mathrm{C}$ towards positive values in the marl that accumulated during a short time interval in the Boreal shortly before $8000 \mathrm{BP}$ is most probably connected with climatically caused soil development. These changes are accompanied with notable improvement of climatic conditions and changes in the vegetation (changes in the content of Betula and Pinus pollen and an increase in broad-leaved trees). 
We have earlier established essential changes in the isotope content at many sites in Estonia; they have been fixed also in South Finland. According to pollen stratigraphy they took place in the Boreal. In Ilmjärv we established the age of this event as $8000 \mathrm{BP}$ by using AMS ${ }^{14} \mathrm{C}$ dating from macrofossils. A fixed sharp increase in $\delta^{13} \mathrm{C}$ and $\delta^{18} \mathrm{O}$ values in many lake marl profiles in Upper Estonia and South Finland is rather close in time and might be used as a stratigraphical stratum which delineates a certain stage in soil development.

\section{ACKNOWLEDGEMENT}

This study was supported by the Estonian Science Foundation (grant No. 4133).

\section{REFERENCES}

Brauer, A. 1990. Preliminary results of $\delta^{13} \mathrm{C}$ and $\delta^{18} \mathrm{O}$ analyses of lake marls from southern Finland. In Proceedings of the Workshop at Lammi Biological Station, 4-6 June 1990 (Saarnisto, M. \& Kahra, M., eds.), pp. 95-102. Geol. Surv. Finland, Helsinki.

Dean, W. E. 1999. The carbon cycle and biogeochemical dynamics in lake sediments. J. Paleolimnol., 21, 375-393.

Eicher, U. 1995. Stable oxygen and carbon isotope analyses on lacustrine carbonate sediments. In Problems of Stable Isotopes in Tree-Rings, Lake Sediments and Peat-Bogs as Climatic Evidence for the Holocene (Frenzel, B., ed.). Palaeoclimate Res., 15, 29-38.

Gat, R. G. \& Lister, G. S. 1995. The "catchment effect" on the isotopic composition of lake waters; its importance in palaeolimnological interpretations. In Problems of Stable Isotopes in TreeRings, Lake Sediments and Peat-Bogs as Climatic Evidence for the Holocene (Frenzel, B., ed.). Palaeoclimate Res., 15, 1-5.

Grimm, E. C. 1990. TILIA and TILIAGRAPH. PC spreadsheet and graphics software for pollen data. INQUA, Working Group on Data-Handling Methods, Newsletter, 4, 5-7.

Hammarlund, D., Aravena, R., Barnekow, B., Buchart, B. \& Possnert, G. 1997. Multi-component carbon isotope evidence of early Holocene environmental change and carbon-flow pathways from a hard-water lake in northern Sweden. J. Paleolimnol., 18, 219-233.

Hu, F. S., Oswald, W. W., Brubaker, L. B. \& Kling, G. W. 2000. Geomorphic and climatic controls over Holocene soil development on the Arctic Foothills of Alaska. In Ecological Society of America, 85th Annual Meeting, 6-10 August 2000; Snowbird, Utah, p. 204.

Kelts, K. \& Talbot, M. R. 1990. Lacustrine carbonates as geochemical archives of environmental change and biotic-abiotic interactions. In Ecological Structure and Function in Large Lakes (Tilzer, M. M. \& Serruya, C., eds.), pp. 290-317. Springer, Berlin.

Koff, T. 1998. Pollen influx in Lake Matsimäe and its catchment. Proc. Estonian Acad. Sci. Biol. Ecol., 49, 247-258.

Koff, T. 2001. Pollen influx into Tauber traps in Estonia in 1997-1998. Rev. Palaeobot. Palynol., 117, 53-62.

Koff, T., Punning, J.-M. \& Kangur, M. 2000. Impact of forest disturbance on the pollen influx in lake sediments during the last century. Rev. Palaeobot. Palynol., 111, 19-29.

Laasimer, L. 1965. Eesti NSV taimkate. Valgus, Tallinn.

Lotter, A. F., Eicher, U., Birks, H. J. B. \& Siegenthaler, U. 1992. Late Glacial climatic oscillations as recorded in Swiss lakes sediments. J. Quat. Sci., 7, 187-204. 
McKenzie, J. A. 1985. Carbon isotopes and productivity in the marine environment. In Chemical Processes in Lakes (Stamm, W., ed.), pp. 99-118. John Wiley, New York.

Moore, P. \& Webb, J. A. 1978. An Illustrated Guide to Pollen Analysis. Hodder and Stoughton, London.

Pirrus, R. 1983. Vooremaa maastikukaitseala geoloogia ja järvede areng. Ms. Institute of Geology, Academy of Sciences of the Estonian SSR, Tallinn.

Pirrus, R., Rõuk, A.-M. \& Koff, T. 1987a. Geology and development of a kettle hole on the Laiuse drumlin (eastern Estonia). Proc. Acad. Sci. Estonian SSR Geol., 36, 1-5 (in Russian).

Pirrus, R., Rõuk, A.-M. \& Liiva, A. 1987b. Geology and stratigraphy of the reference site of lake Raigastvere in Saadjärve drumlin field. In Palaeohydrology of the Temperate Zone, II, Lakes (Raukas, A. \& Saarse, L., eds.), pp. 101-122. Valgus, Tallinn.

Punning, J.-M. \& Koff, T. 1997. The landscape factor in the formation of pollen records in lake sediments. J. Paleolimnol., 18, 33-44.

Punning, J.-M., Martma, T. \& Vaikmäe, R. 1984. Light isotope variations in carbonate sediments and their palaeogeographic value. ZFJ Mitteilungen, 84, 329-336.

Punning, J.-M., Toots, M. \& Vaikmäe, R. 1987. Oxygen-18 in Estonian natural waters. In Fourth Working Meeting "Isotopes in Nature", Held in Leipzig, 22-26 Sept, 1986: Proceedings (Wand, U. \& Strauch, G., eds.), pp. 545-552.

Punning, J.-M., Koff, T., Tann, R. \& Lukki, T. 1997. The sensitivity and adaptation of ecosystems to the disturbances: a case study in northeastern Estonia. Mitigation and Adaptation Strategies for Global Change, 2, 1-17.

Punning, J.-M., Koff, T. \& Martma, T. 2000. Stable isotope and pollen records in marl sections from some Estonian lakes and their palaeoclimatic interpretation. In Estonia: Geographical Studies, 8 (Punning, J.-M., ed.), pp. 19-33. Estonian Acad. Publ., Tallinn.

Raukas, A., Saarse, L. \& Veski, S. 1995. A new version of the Holocene stratigraphy in Estonia. Proc. Estonian Acad. Sci. Geol., 44, 201-210.

Reintam, L. 1996. Environmental performances of the soil cover. In Estonian Environment: Past, Present and Future (Raukas, A., ed.), pp. 142-145. Ministry of the Environment of Estonia, Tallinn.

Talbot, M. R. 1990. A review of the paleohydrological interpretation of carbon and oxygen isotopic ratios in primary lacustrine carbonates. Chem. Geol., 80, 261-279.

Wachniew, P. \& Rozanski, K. 1997. Carbon budget of a mid-latitude, groundwater-controlled lake: isotopic evidence for the importance of dissolved inorganic carbon recycling. Geochim. Cosmochim. Acta, 61, 2453-2465.

Whittington, G., Fallick, A. E. \& Edwards, K. 1996. Stable oxygen isotope and pollen records from eastern Scotland and consideration of Late-glacial and early Holocene climate change for Europe. J. Quat. Sci., 11, 327-340.

\title{
Ilmjärve (Kesk-Eesti) järvelubja lasundi isotoop- ja õietolmustratigraafia
}

\author{
Jaan-Mati Punning, Tiiu Koff, Tõnu Martma ja Göran Possnert
}

Ilmjärve läbilõike isotoopkõverate iseloomulikumaks jooneks on $\delta^{13} \mathrm{C}$ väärtuste lühiajaline maksimum $c a 8000$ aastat tagasi, järgnev 3,5promilline langus ja edasi peaaegu konstantsed väärtused kuni 4000 aastat tagasi moodustunud setetes. Ligikaudu samal ajal leidis aset $\mathrm{ka} \delta^{18} \mathrm{O}$ väärtuste lühiajaline suurenemine. 
Õietolmuanalüüsi andmetel toimusid isotoopsed muutused järvesetetes ajal, kui valgalal seni valitsenud okaspuude kooslusse ilmusid lehtpuud.

Analoogilisi järske isotoopkoostise muutusi oleme varem täheldanud mitme Kõrg-Eesti erineva suuruse ja hüdroloogilise režiimiga järve boreaalse kliimaperioodi aegsetes setetes. Komplekssed uuringud lubavad püstitada hüpoteesi, et järsud muutused isotoopprofiilides on tingitud kliima üldise soojenemise taustal aset leidnud mullatekke intensiivistumisest ja orgaanilise aine sissekande suurenemisest uuritud järvedesse. Isotoopmaksimumid nii Eestis kui ka Lõuna-Soomes on fikseeritud Boreaali lõpus moodustunud settekihtides ja neid võib seega kasutada stratigraafiliste markeritena.

\section{Стратиграфия озерных известей оз. Ильмъярвь (Средняя Эстония) по изотопным и спорово- пыльцевым данным}

\section{Яан-Мати Пуннинг, Тийу Кофф, Тыну Мартма и Гёран Посснерт}

Характерным для изотопных кривых разреза Ильмъярвь является кратковременный максимум величин $\delta^{13} \mathrm{C}$ около 8000 лет назад, за которым следует уменьшение в $3,5 \%$ и далее константные величины до 4000 лет. Одновременно нашло место также кратковременное увеличение величин $\delta^{18} \mathrm{O}$. По данным пыльцевого анализа изменения в изотопном составе озерных отложений происходили во время смены хвойных лесов смешанными.

Аналогичные резкие изменения в изотопном составе озерных известей наблюдались нами ранее в некоторых озерах возвышенной Эстонии различной площади и гидрологического режима. Результаты комплексных исследований позволяют выдвинуть гипотезу, что резкие изменения в изотопных профилях могут быть следствием интенсификации почвообразовательных процессов и увеличением привноса органического вещества в озера на фоне общего потепления климата. Резкие пики $\delta^{13} \mathrm{C}$ кривых, зафиксированные в отложениях раннебореального возраста в некоторых озерах Эстонии и Южной Финляндии, можно использоватъ в качестве стратиграфического маркера. 